Claremont Colleges

Scholarship@ Claremont

Scripps Faculty Publications and Research

Scripps Faculty Scholarship

$1-1-2007$

\title{
When Saturday Comes: The Boundaries of Football Rudeness
}

Tony Crowley

Scripps College

\section{Recommended Citation}

Crowley, Tony. "When Saturday Comes: the Boundaries of Football Rudeness," in Rude Britannia, ed. Nina Gorji, Routledge, 2007, pp. 115-126.

This Book Chapter is brought to you for free and open access by the Scripps Faculty Scholarship at Scholarship @ Claremont. It has been accepted for inclusion in Scripps Faculty Publications and Research by an authorized administrator of Scholarship @ Claremont. For more information, please contact scholarship@cuc.claremont.edu. 


\section{When Saturday comes}

\section{The boundaries of football rudeness}

\section{Tony Crowley}

It is clear that the conventions which govern the use of 'rude' language in public discourse have altered over a generation. It is possible to imagine a Tory patriarch like Ted Heath or a Labour leader like Harold Wilson referring to members of their governing cabinet as 'bastards' in private conversation. But it is difficult to imagine either of these British Prime Ministers using this description in public. Perhaps more importantly, it is open to doubt whether the use of such a term, even if it slipped out by mistake, would have been reported by the leading newspapers and media outlets of the day. It is more likely that the desire on the part of the gatekeepers of culture to protect the linguistic propriety of the political field would have outweighed the temptation to print a controversial story. ${ }^{1}$ Yet John Major's position as Prime Minister in 1993 appeared wholly unaffected by his leaked admission that he didn't sack rebel ministers after a parliamentary vote of confidence because he didn't want 'three more of the bastards' conspiring against him. Indeed the comment may well have enhanced Major's weak image in the eyes of the electorate. His successor, Tony Blair, at least in the early days of his premiership, actively cultivated an association with the 'bad-mouthed' boys and girls of Cool Britannia and his Press Secretary and confidante Alastair Campbell gained a reputation for his use of expletives in his dealings with the media. ${ }^{2}$ There seems then to have been a modification to the 'structure of feeling' associated with this aspect of rudeness in British society. But there is one place in Britain which has been almost automatically linked with forms of rudeness which are socially unacceptable; a location where offensiveness, crudity, insulting behaviour and nastiness constitute not so much the exception as the norm. Or at least this is how it appears in the social imaginary. The aim of this chapter will be to explore this arena in order to determine what it reveals about both British society and its boundaries of rudeness. The site to be considered is the Premiership football ground, when Saturday comes. ${ }^{3}$

One text which focuses much of the debate both about rules of public rudeness and football fans is Tony Harrison's V., first published in 1985 in the aftermath of the Miners' Strike against the Thatcher government. It is perhaps difficult to recall some twenty years later the furore which this poem, or at least 
a film of the poet reading it, caused in British public life. First scheduled to be broadcast on Channel 4 in a mid-evening slot, the film was re-scheduled for $11.30 \mathrm{pm}$ on 4 November 1985 in response to the furious protests of selfappointed moral guardians, the Tory press, and Thatcherite politicians. The Daily Express inaccurately described the poem as a tribute to the Miners' leader Arthur Scargill (the epigram is a quote from Scargill on his father's belief in the power of words), and warned that a 'torrent of foul language will be seen in a Channel 4 programme by respected Newcastle poet Tony Harrison' (Harrison 1989: 42). And the Daily Mail described the film as containing 'a torrent of four-letter filth ... which will unleash the most explicitly sexual language yet beamed into the nation's living rooms' (Harrison 1989: 40). Both papers quoted Tory MPs. Gerald Howarth asserted that 'this is another case of the broadcasters trying to assault the public by pushing against the barriers of what is acceptable' and described Harrison as 'another probable Bolshie poet seeking to impose his frustrations on the rest of us' (Harrison 1989: 41). While Teddy Taylor 'appealed to Channel 4 chiefs to see sense' and observed that 'obviously Channel 4 is the place for experiment, and for a bit of variety, but a poem stuffed full of obscenities is clearly so objectionable that it will lead to the Government being forced to take action it would prefer not to have to take' (Harrison 1989: 41). The action which the government was allegedly reluctant to undertake was the setting up of a new media monitoring unit; the fact that the Home Secretary had already announced the creation of the Broadcasting Standards Council was conveniently forgotten.

The Tory reaction to the poem was constituted by two ideological tendencies. The first was the concern for the damaging effect of 'bad language' on the moral fabric of British social life. The articulation of this worry by a party which treated established communities - not least mining villages - with contempt, which bred cynicism with its corruption of public office, and which promoted laissez-faire deregulation by its neo-liberal privatization mania, is noteworthy. The second ideological factor was the Thatcherite hatred of the working class, manifested not least in its attitude towards football fans. Yet despite the fact that what Harrison had produced in his poem was precisely the image of the football supporter which most Tories held (an uneducated, drunk and violent working-class man), it was the 'foul language' fear which dominated the response, an indication in itself of the special place which 'bad language' has in the Tory code of values.

One of the aims of $V$. is to speak for those who are politically and culturally silenced, to articulate the sentiments of the socially inarticulate. And it does so in a nuanced, powerful and seductive manner in a crucial section in which the football fan, writing graffiti on the headstones in a graveyard, makes an accusation against the poetic persona:

Don't talk to me of fucking representing

the class yer were born into any more.

\section{Yer going to get 'urt and start resenting}

it's not poetry we need in this class war.

(Harrison 1989: 22)

The poet responds by challenging him to authorize his graffiti by inscribing his name:

He took the can, contemptuous, unhurried and cleared the nozzle and prepared to sign the UNITED sprayed where mam and dad were buried.

He aerosolled his name. And it was mine.

(Harrison 1989: 22)

What Harrison attempts is a partial identification between the poet and the working-class football fan; the suggestion is that this is perhaps what Harrison himself would have been without the scholarship to a grammar school and the university education in Classics. The rude anti-social football thug is made to represent, patronisingly at times, the person racking the benefit of culture and education; in its extreme form, the untamed 'foul-mouthed' racist.

$V$. is by no means Harrison's best work, but it is a bold and challenging piece which uses vernacular experimentation in the service of a critique of the divisiveness, bitterness and social violence caused by Thatcherism. And while its presentation of particular forms of unity as the means of resolving social division is in fact exclusive (heterosexual domesticity is the model), the poem articulates a keen sense of the historical and material basis of the aesthetic, as its ending demonstrates:

Beneath your feet's a poet, then a pit.

Poetry supporter, if you're here to find

how poems can grow from (beat you to it!) SHIT

find the beef, the beer, the bread, then look behind.

(Harrison 1989: 33)

Yet although $V$. presents an angry denunciation of Thatcherite ideology and its effects, as noted earlier it also colludes with that ideology in its representation of the football fan as the site of anti-social behaviour, the product of a failure of education and culture, in short the embodiment of rudeness. It is with the behaviour of that stereotypical figure that the rest of this essay is concerned.

Bourdieu's model of social practice offers a means to analyse, at the level of language, the injustices of class in contemporary Western societies. Those at the bottom of the social order are dispossessed and disadvantaged by the division of linguistic and cultural capital which is structurally tied to the distribution of economic capital. The poor are effectively socially silenced by their use of illegitimate language, often in the form of awkwardness, incoherence or 
unacceptable 'rudeness', when confronted by contexts which demand specific forms of legitimate language. Thus in $V$. the football fan is sensitive to the social implications of the linguistic differences between his own speech and that of the poet. Responding to the poetic persona's use of the word 'aspiration' the skin retorts:

\section{Aspirations, cunt! Folk on t'fucking dole}

'ave got about as much scope to aspire

above the shit they're dumped in, cunt, as coal

aspires to be chucked on t'fucking fire.

(Harrison 1989: 17)

The skin responds angrily to the use of the Latinate 'aspiration' and his violent rejection of the poet's patronizing effort to treat him as though he were actually silent and thus to speak on his behalf is prompted by a pun on the name 'Rimbaud' (which he hears as 'Rambo'). In answer to the attempt to include him in the poem - 'the reason why I want this in a book/'s to give ungrateful cunts like you a hearing!' - the skin replies

Ab've told yer, no more Greek. . . That's yer last warning! Ab'll boot yer fucking balls to Kingdom Come.

They'll find yer cold on t'grave tomorrer morning.

So don't speak Greek. Don't treat me like I'm dumb.

(Harrison 1989: 19)

$V$. is in part a poetic exploration of linguistic capital and its social power. The poetic persona in this account has the practical sense and social competence which derives from a particular educational and cultural training. His language conforms to the structural demands of a specific discursive field and is therefore recognized as legitimate; he is empowered to speak. And since 'all linguistic practices are measured against the legitimate practices, i.e. the practices of those who are dominant' (Bourdieu 1992: 53), the skin, lacking such competence, is doomed to speak a language which is classified as illegitimate, one which falls outside the boundaries of acceptable speech and which is thus unheard or misrecognized. A scene from another literary text illustrates Bourdieu's point. In Irvine Welsh's Trainspotting two characters are facing theft charges in court. One, Renton, is able to manipulate the code of legitimate language to present his defence. Asked by a magistrate if he stole books to sell for drug money he answers:

- Naw. Eh, no, your honour. They were for reading.

Renton's self-correction (naw-no) represents a move towards conformity with the rules of formal discourse demanded by the context of the law court. The shift is consolidated in his response to the magistrate's scepticism about the likelihood of his reading Kierkegaard:

- I'm interested in his concepts of subjectivity and truth, and particularly his ideas concerning choice; the notion that genuine choice is made out of doubt and uncertainty, and without recourse to the experience or advice of others.

Renton's co-accused, Spud, replies to the magistrate's question about stealing to pay for heroin:

- That's spot on man ... eh . . ye goat it, likesay.

Sentenced to ten months in prison (Rentor receives a fine and a suspended sentence), Spud can only mumble:

- Thanks ... eh, ah mean ... nae hassle, likesay ...

(Welsh 1993: $165-6)^{4}$

This representation of the language of the working class echoes that made by an early twentieth-century British sociologist, C. F. G. Masterman, in his From the Abyss: Of Its Inhabitants: By One of Them (1902). Writing as a member of the working class, like Harrison, Masterman represents its speech as a form of silence, noting for example that working-class speakers 'never reach the level of ordered articulate utterance; never attain a language that the world beyond can hear' (Masterman 1902: 20). Yet Masterman's work offers another account of a crowd of working-class men:

They drifted through the streets hoarsely cheering, breaking into fatuous irritating laughter, singing quaint militant melodies.... As the darkness drew on they relapsed more and more into bizarre and barbaric revelry. Where they whispered now they shouted; where they had pushed apologetically, now they shoved and collisioned and charged. They blew trumpets, hit each other with bladders; they tickled passers-by with feathers; they embraced ladies in the streets, laughing generally and boisterously. Later the drink got into them, and they reeled and struck and swore, walking and leaping and blaspheming God.

(Masterman 1902: 3)

Rather than silence or awkward articulation, Masterman describes an excess of noise: cheering, laughter, singing, revelry, shouting, trumpets, swearing and blaspheming God. But Masterman's account ultimately supports Bourdieu's theoretical distinction between legitimate and illegitimate language: it is not that the working class, or indeed other marginalized groups, do not speak, but 
that their words do not belong to what Masterman calls 'ordered articulate utterance'. The working class is not silent, it is socially silenced by symbolic power; its speech becomes mere noise, inarticulacy, or rudeness.

Masterman's carnivalesque representation of the working-class crowd at the turn of the century sounds remarkably like a scene from contemporary football before a big game or after an important win. Yet an account of the behaviour of football crowds as simply chaotic and carnivalesque is as misleading as one which depicts such crowds as composed of the socially offensive thugs of the Thatcherite social imaginary. Both versions depict the football crowd as essentially random, disorderly and threatening, and thus not able to be understood by measured analysis. However, my point in this essay will be that the activity of the football crowd - the singing, the shouting, the movement, the laughter is open to explanation by means of an application of Bourdieu's account of the legitimacy of specific modes of behaviour in a particular context. With regard to language, many of the speech acts of football fans are unacceptable beyond the walls of the stadium; within the ground they are subject to the rules and norms of a social field which constitutes legitimate and illegitimate speech. When Saturday comes the boundaries of rudeness change.

Before attempting an analysis of the conventions and the functions of football rudeness it is worth making two related points. First, the norms are historically specific: things which were acceptable in the $1970 \mathrm{~s}$ are clearly no longer tolerated. Examples at Premiership grounds include chants which openly threaten violence ('You're gonna get your fucking heads kicked in', 'You're going home in a fucking ambulance') and racist songs, noises and chants (this will be considered later). Second, the composition of the football audience has changed for a number of reasons: the modifications to the stadiums after Hillsborough, the trendiness of football after Italia 1990, the glamourization of the game through satellite television coverage, corporatization and the consequent massive increases in ticket prices, to name but a few. Football is no longer simply a working-class game - at least in terms of those who go and watch it regularly. But despite the fact that the conventions and the nature of the audience have been transformed, behaviour in the stadium is still manifested in patterns which, though flexible, are analytically comprehensible. There are things which are acceptable and things which are, to use a key phrase, 'not on'.5 For example it isn't on to sing another club's song, except perhaps in a mocking manner. It would be peculiar to sing on your own for any length of time (though shouting a comment is acceptable). It would be extraordinary to praise an opposition player lying injured; though it would be unusual not to applaud any seriously injured player as he left the ground. Interrupting a minute's silence in memory of the dead is unacceptable and if it occurs is usually attributable to a few individuals; organized chanting over the silence would represent a serious departure. ${ }^{6}$ It is permissible to laugh if the referee runs into a player of the opposing team, but not if two of your own players collide ... and so on. More than anything else, it is possible, if not expected, to be rude, either about the opposition, or, more infrequently, about members of your own team. But the sense of what is rude in this context is socially distinct. The rudeness of Harrison's skin or Spud in Trainspotting is the result of the process whereby working-class people are denied access to forms of linguistic capital and are thus produced as ignorant (in the neutral sense of the term). The rudeness of the football ground is different: rather than unknowing, the rudeness of the football fan is a form of deliberate and circumscribed offensiveness.

If someone were to shout an insult at a stranger or group of strangers in the street or in a park they would be liable either to a response from that person, or in given circumstances, an intervention by the forces of the State. Yet the following are all commonplaces inside football grounds: 'You're shit and you know you are', 'Who the fucking hell are you?', 'fuck off $\mathrm{X}$ ' ... Why would this be offensive in one instance and taken as normal or standard in another? The answer lies precisely in the fact that these are generic chants shouted or sung by thousands of people in a specific context. Rather than insults in the familiar sense, these are formulaic expressions in which the particular content is overridden by the nature of the act to which they belong. When a crowd chants 'the referee's a wanker', what is not in question is the private behaviour of a given individual (it's unusual for a referee's name to be used). Instead an illocutionary act is performed whose force is that of a general expression of antagonism. But in order for a performative to occur there have to be conventions which govern its use and form. For example, such a chant would rarely occur before the match started and never when the referee has just given your own side a penalty. Moreover only minor alterations can sensibly be made to the form: 'the linesman is a wanker' would be peculiar ('fuck off linesman' is the accepted call); 'the referee's a bastard', or 'the referee's a Scouser/Geordie/Cockney' are permissible, though 'the referee's an idiot' and 'the referee's a bigot' would be

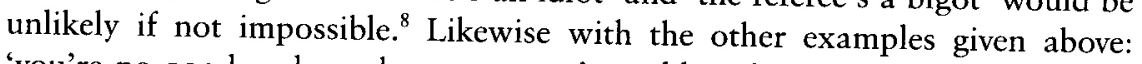
'you're no good and you know you are' wouldn't do, nor would 'you're rubbish'; 'Who the bloody hell are you?' would sound peculiar, as would 'bugger off X', 'go home X' and so on. The point about this type of performative is that it needs to be as conventionally offensive as possible. Yet even if these aren't insults in the ordinary sense of the term, they still seem to be expressions of extreme forms of rudeness; but if that were their function then they would have to be taken as clear failures. Given that one of the purposes of intentional rudeness is to inflict harm upon another, then the chanting of football songs at players or the referee seems to be peculiarly ineffective. This seems to be well recognized, not least in the testimony of ex-players that the taunts of a crowd actually spurred them on, or in the fact that referees make unpopular decisions constantly and seem little swayed by the words directed against them. Moreover few football fans seem to think that their words have much effect in this sense. But then the question arises: Why, given their practical inefficiency as insults, are such chants sung? The answer lies not in the antagonistic illocutionary force but in the perlocutionary effects of the rude chanting: the function of these 
songs is not to insult, but to produce a communal bond and identity through repeated performances of empty hostility.

The apparently excessive rudeness at football grounds constitutes the ongoing performance of a particular type of identity which demands specific forms of knowledge (if, what, when, how things can be articulated). This identity is not so much concerned with loyalty to the club or even the team (though both are of course included) since the reality is that both club (in terms of ownership) and team (in terms of personnel) can change radically whilst still attracting support. Being a football fan, rather than simply being a supporter of a club, is a question of occupying a specific social space and time and performing communal acts of identity. One such act is the chanting of (and listening to) songs whose exaggerated rudeness exemplifies the intensity of the identification. Football fans sing and shout in ways which are shared and which are socially unusual (the same chants anywhere else would infringe the law). The chanting of what sounds like abuse, but which is more like the production of commonality, is one of the elements of being a fan (and the fans of particular clubs share the, often traditional, rude songs and chants of that club). In this sense the boundaries of rudeness belong precisely to the constitutive boundaries of identity.

There are songs and chants which, if still rude by normal standards, include forms of irony, mockery or wit. Beating a team easily sparks the chant 'Can we play you every week?', or, hitting two targets at once, 'Are you $\mathrm{X}$ in disguise?' - where $X$ is the name of a local rival, thus suggesting that both teams are poor. Players perceived to be overweight are doomed to hear 'Who ate all the pies? Who ate all the pies? You fat bastard, you fat bastard, you ate all the pies'. The arrival of a small number of visiting fans is often met with 'What's it like to see a crowd?' One player, Andy Goram of Rangers, was diagnosed with a form of schizophrenia and was greeted by: 'Two Andy Gorams, there's only two Andy Gorams'. The shout when Liverpool scored against Swiss team FC Basle was 'You're not yodelling any more'. Parody is a familiar technique, as in opposing fans' version of the Liverpool song 'You'll Never Walk Alone' with the chorus 'You'll never work again', referring to the high unemployment rates in the city during the 1980s and 1990s. The folksong 'In My Liverpool Home' (not in fact sung by Liverpool supporters) is recast as 'In your Liverpool slums, in your Liverpool slums, you look in the dustbins for something to eat, you find a dead rat and you think it's a treat ...'; and in the same vein Manchester United fans sing 'Feed the Scousers, do they know it's Christmas time?', to the tune of Live Aid's 'Feed the World'. Wittier chants are often responses to insults from opposing fans. When Everton supporters mocked Swindon followers with the threat of relegation, 'going down, going down, going down', they were met with the rejoinder 'so are we, so are we, so are we . . ' And when Liverpool reached the Champions League final in 2005, held in Istanbul, their fans' answer to the condescending 'Champions League? You're having a laugh' was 'Champions League? We're having Kebabs'. In response to the taunt 'you're not famous any more', made by Chelsea fans at Liverpool's ground, the home fans took to chanting 'history, history, you can't buy history', and singing 'Money Can't Buy You Love'. Another reference to the dubious wealth of the Chelsea owner Roman Abramovich was made by the fans of Norwich, whose managing director happens to be a celebrity chef: 'We've got a supercook, you've got Russian crook'.

There are, however, songs and types of chanting which are rude and socially offensive in other ways. Communal expression of sexism is relatively rare at football grounds, though given the dominant culture of male heterosexuality, sexist sentiment is never far away. The song aimed at David Beckham which referred to his wife ('Posh Spice takes it up the arse') is a good example of this form of chanting, which tends to be personal and specific rather than generic. The same is true of the more recent development of homophobic abuse. One player, Graeme Le Saux, was constantly baited with references to homosexuality and anal sex; suspicion focused on the fact that he didn't read the tabloids and had cultural interests which differed from those of most footballers. And opposing fans frequently taunt the fans of Brighton FC (Brighton was for a long time Britain's gay capital) with 'we can see you holding hands'. But there is one mode of rude chanting which is hardly heard at the grounds of Premiership football clubs, and this is surprising given its prevalence in the previous generation. What strikes anyone who attended first division football matches in the 1970 s and 1980s in Britain about today's Premiership games is the almost complete disappearance of racist abuse. Harrison's $V$. serves as a reminder that it wasn't always so:

Jobless though they are how can these kids, even though their team's lost one more game, believe that the 'Pakis', 'Niggers', even 'Yids' sprayed on the tombstones here should bear the blame?

(Harrison 1989: 16)

It should be made clear that what is not being argued is that racism has disappeared from football, nor that those who attend the games are not racist, nor that it is changes in the audience that have led to the silencing of racist abuse (middle-class racism runs quite as deep as its working-class counterpart). Nonetheless, it is a fact that racist chanting is very rarely heard at Premiership grounds and it is worth pondering the causes and implications of this change in the boundaries of permissible social rudeness on Saturday afternoons. Among the many reasons two particular and one more general suggest themselves. The first has to be the sheer number of black players in the game and their achievements. The fact that for a considerable period black players have been among the outstanding players in the Premiership makes the expression of a particular type of racism awkward (it's hard to call someone lazy or talentless for example if they have just scored a brilliant goal for or against your team). On its own, 
however, it is doubtful whether this would have been enough, as was demonstrated by the treatment meted out to John Barnes when he played for the English national team in the $1980 \mathrm{~s}$. A second factor which changed the attitude to black players in football was the set of anti-racist strategies introduced by the major football organizations, including the clubs, in the 1990s (principally the 'Kick Racism Out Of Football' campaign). This includes, in the Premiership grounds, regular anti-racist announcements before games, in signs at the ground and in the programme, and the making of racist chanting an offence liable to expulsion. It is also questionable, however, whether this would have worked (how can large numbers of people be ejected for singing a racist song?) without a third factor. This was the slow but evident change in the structure of feeling associated with race and racism in British society in the past generation. ${ }^{10}$ Again this is not to underestimate the depth to which racism runs in contemporary Britain, but it is to recognize an important social shift in process. There are complex reasons for this development, demographic, economic and cultural, but among other factors State intervention has been important: explicit ordinances have included a mix of education, with the introduction of clear anti-racist policies in schools and the active promotion of multiculturalism, and law, with the Race Relations Act (1976) and its amendments (2000 and 2003 - the latter to conform to European Union policy). Whatever the precise causes, the net effect of the shift is evinced by the fact that not only is racist abuse rarely heard in Premiership grounds, but that when black England players were racially abused in a game against the Spanish national team in Madrid in November 2004 the outcry was based on the sense that 'we don't do that sort of thing'."

Such a sentiment is clearly predicated on the cultural hegemony of antiracism in the game. And one of the implications of the role of the State in the forging of this development may be to give those opposed to State intervention on such matters pause for thought; for all of the attacks on Political Correctness this is one area where it has been successful. Of course, as was stated earlier, this is not to claim that football is free from racism since this would be ludicrous; cultural hegemony does not permeate social reality. There are very few Asian players, almost no non-white managers or administrators, and for a sport dominated by black talent there are few enough black faces in the crowds. But to those who would challenge the extent of the success of anti-racism in football, it is worth pointing out that Premiership football grounds are one place in Britain where it is unlikely that a fit and talented non-white man will be racially abused or that children will hear racist comments; and in both cases if the offence takes place there is immediate recourse. A generation ago racist rudeness was part of the social competence of the football fan. These days you can be rude at Premiership football grounds, but the boundaries of rudeness have altered such that the socially offensive practice of racism is disallowed. The rules, the game and the field have changed.

\section{Notes}

1 Pierre Bourdieu uses the notion of a social 'field' as a structured set of contexts in (economic, cultural, symbolic, linguistic) and the use of various forms of capital capital into another (Bourdieu 1992:57-65, and permit the conversion of one form of

2 The shift is not confined to Britin 57-65, 229-51).

Albert Reynolds described a Britain. In 1992 the Irish Taoiseach (Prime Minister) a furore and dospite his citing a diction to him by a journalist as 'crap'; it caused a furore and despite his citing a dictionary definition to defend his use of the word to mean 'nonsense' he was forced to withdraw and to defend his use of the word leader of the Irish Seanad (Senate) Mary O'R and apologise. Ten years later the with the same term without reaction. In the USA in July a political opponent regretted the comment made in 1971 . In the USA in July 2005 Henry Kissinger regred the comment made in 1971, revealed in declassified state documents, that 'the Indians are bastards' (President Nixon, his interlocutor, called the Indian Prim Minister Indira Ghandi an 'old witch') Evidently having, called the Indian Prime limits of linguistic rudeness, Vice-President Cheney having a different sense of the June 2004 telling one of his political opponents 2004 George Bush, on of his political opponents to 'go fuck yourself'. In October 2004 George Bush, on the campaign trail, called a reporter 'a major league asshole'. In an electoral year their words seemed to do little serious harm.

3 Because of the demands imposed by Sky television, many Premiership games no longer take place on Saturday aftemoon, bett that remains the residual focal point for British soccer fans. I am drawing on my own experience as a life-long focal point for and a regular at Anfield. This means of experience as a life-long Liverpool fan sense of limited, but the point is to course that the evidence is partial, in the Liverpool or Anfield. I refer in the to make a general case and not one specific to here do not apply to non-Premiership games. 4 Both do not apply to non-Premiership games.

4 Both Harrison and Welsh represent a working-class speaker who has managed to of disadvantaged groups are means of his education. The socially mobile members

of disadvantaged groups are of course usually the most linguistically adept in being
able to use a variety of codes.

'Not on' is originally a sporting usage: 'Acceptable; played according to the rules of
a game (originally esp. in Snooker) practicable, feasible. Freq in negative; conforming to a standard of behaviour, etc. first recorded instance is . in negative contexts, esp. in it's (just) not on' (OED). It

Taunting referstance is fron

Taunting references to the death of officials and supporters of Manchester United at
Munich (1958), or Liverpool supporters at Hillsborough olic abuse and sometimes violence. The bitternorough (1989), are met with vitriclubs led, in a recent example, to Liver The bitterness of the rivalry between these two a United player. The fact that the crowd's fans chanting gleefully about an injury to the injury was serious, and the frowd's reaction turned when it became clear that proves the rule. 'Lacking experience of 'rude' records this distinction. The $O E D$ gives the senses: 'Lacking experience or skill in, without proper knowledge of, unaccustomed to, something', first used in 1366, and 'Unmannerly, uncivil, impolite; offensively or deliberately discourteous' particularly with regard to speech or actions, first recorded in 1386 . The word derives from the Latin rudis: unwrought, unformed,
inexperienced.

8 In the chant 'the referee's a Scouser/Geordie/Cockney', the identity of the opposing team determines the putative identity of the referee. The use of local and regional Canel in 1859 in his form of the 'blason populaire', a term coined by Auguste lauded themselves and observations on customs in which people from Normandy lauded themselves and their own area while deriding others (see Gaidoz and Sébillot
1884). Contemporary football examples include 'we hate the Cockneys/Geordies/ 
Scousers', 'we all hate Mancs and Mancs and Mancs', 'Southerners, Southerners, Southerners'.

9 As with sexist chanting, homophobic abuse tends to be opportunistic and occasional rather than ritualized and part of the received repertoire; this is why it sounds more vicious and crude. It is often a response to tabloid news stories.

10 Raymond Williams describes structures of feeling as 'meanings and values as they are actively lived and felt' which have variable relations with formalized or systematic beliefs or codes; they are forms of practical consciousness which he refers to, significantly in this context, in terms of 'characteristic elements of impulse, restraint, and tone'. He cites the history of a language as the material location of changes in structures of feeling (Williams 1977: 132).

11 In fact this sense is misplaced since racist chanting does take place at England games, as for example in a game against Turkey in 2004. Though the chanting is now directed towards opposition players rather than black players in an England shirt, the national side is still a focus for racists.

\section{References}

Bourdieu, P. (1992) Language and Symbolic Power, Cambridge: Polity. Gaidoz, H. and Sćbillot, P. (1884) Blason populaire de la France, Paris: Cerf. Harrison, T. (1989) V., 2nd edn, Newcastle upon Tyne: Bloodaxe Books.

Masterman, C. F. G. (1902) From the Abyss: Of Its Inhabitants: By One of Them, London: Johnson.

Welsh, I. (1993) Trainspotting, London: Secker and Warburg.

Williams, R. (1977) Marxism and Literature, Oxford: Oxford University Press. 